\title{
Study on Effect of Plant Growth Regulators and Boron on Fruit Yield Attributes of Tomato (Solanum lycopersicum Mill.)
}

\author{
Shweta Gupta ${ }^{1^{*}}$ and Deepti Patel ${ }^{2}$ \\ ${ }^{I}$ Department of Vegetable Science BTC CARS, Bilaspur (C.G.), India \\ ${ }^{2}$ Department of Horticulture, Collage of Agriculture, Raipur (C.G.), India \\ *Corresponding author
}

\begin{tabular}{|c|c|}
\hline & A B S T R A C T \\
\hline $\begin{array}{l}\text { Ke y w o r d s } \\
\text { GA3, } \\
\text { NAA, Boron } \\
\text { and Tomato }\end{array}$ & $\begin{array}{l}\text { An experiment Study on effect of Plant Growth Regulators and Boron on Growth, Yield } \\
\text { and Quality of Tomato (Solanum lycopersicum Mill.) was conducted at Horticultural } \\
\text { Research cum Instructional Farm, Barrister Thakur Chhedilal College of Agriculture \& } \\
\text { Research Station. Bilaspur (C.G.) during Rabi season of 2017-18. The experiment was laid } \\
\text { out in Randomized Block Design (RBD) replicated thrice including ten treatments viz., }\end{array}$ \\
\hline Article Info & T5 (NAA@100 ppm) T6 (Boron@75 ppm),T7 (GA3 @50 ppm + Boron@75 ppm), \\
\hline $\begin{array}{l}\text { Accepted: } \\
26 \text { April } 2020 \\
\text { Available Online: } \\
10 \text { May } 2020\end{array}$ & $\begin{array}{l}\text { T8 (GA3 @ } 75 \mathrm{ppm}+\text { Boron @ } 75 \mathrm{ppm}) \text {, T9 (NAA @ } 75 \mathrm{ppm}+\text { Boron @ } 75 \mathrm{ppm}) \text { and } \\
\text { T10 (NAA @ } 100 \mathrm{ppm}+\text { Boron @ } 75 \mathrm{ppm}) \text {. The significantly maximum number of fruit } \\
\text { per cluster }(8.33) \text {, maximum number of fruit per plant }(26.46) \text {, fruit length }(7.92 \mathrm{~cm}) \text {, fruit } \\
\text { diameter }(4.47 \mathrm{~cm}) \text {, fruit weight }(56.22 \mathrm{~g}) \text {, average yield per plant }(1.69 \mathrm{~kg}) \text {, yield }(490.81 \\
\text { q/ha) was recorded in T10(NAA @ } 100 \mathrm{ppm}+\text { Boron @ } 75 \mathrm{ppm}) \text {. }\end{array}$ \\
\hline
\end{tabular}

\section{Introduction}

Tomato (Solanum lycopersicum MILL.) is one of the most important solanaceous vegetable crop grown throughout the world because of its wider adaptability, high yielding potential and suitability for various uses in fresh as well as processed food industries. In world, it ranks second in importance after potato, but tops in the list of processed vegetables. Tomato being a moderate nutritional crop is considered as good source of potassium, folate, vitamin E, soluble and insoluble dietary fibers, vitamin A, C including calcium and carotene.
Plant growth regulators (PGRs) are used extensively in horticulture to enhance plant growth and improve yield by increasing number of fruits, fruit set and size (Batlang, 2008 and Serrani et al., 2007). Plant growth substances are essential for growth and development of plants. Similarly it plays an important role in flowering, fruit setting, ripening and physiochemical changes during storage of tomato.

In India, tomato is grown on an area of 0.79 million hectare with an annual production of 17.39 million tonnes (Anon. 2015). In Chhattisgarh, tomato is being cultivated in 
area of 52.89 thousand hectare and production of 868.60 thousand tonnes with a productivity of 15.89 tonne/ha (Anon. 2015). It is cultivated in almost all districts of Chhattisgarh viz., Raigarh, Durg, Jashpur, Sarguja, Jagdalpur, Bemetra, Balodabazar, Kabirdham, Raipur, Kondagaon, Mungeli, Balod, Bilaspur, Surajpur and Rajnandgaon.

Plant growth regulators and micronutrients are an important part of plants and affect their physiology in several ways. Micronutrients and plant growth regulators together play an important role. They help in both vegetative and reproductive growth and are indispensable for the product of foliage flowers, fruits and seeds.

\section{Materials and Methods}

\section{Number of fruits per cluster}

The number of fruits per cluster on five tagged plants was recorded under each treatment combination.

\section{Number of fruits per plant}

Fruits from all the picking were counted for each selected plants.

\section{Fruit length (cm)}

From five selected plants, five fruits were randomly selected and with the help of Vernier calipers the length of fruit, from tip to the base was measured of each fruit, then the mean length was worked out.

\section{Fruit diameter $(\mathrm{cm})$}

Five fruits from the selected plants were selected randomly and with the help of Vernier calipers the fruit diameter, of all fruits was measured respectively. Then the mean breadth was worked out.

\section{Fruit weight}

Fruit from the tagged plants were selected randomly, and average weight per fruit was calculated.

\section{Average yield per plant (kg)}

The fruits picked in each harvest were weighed and cumulative yield was expressed in kilograms. The values were recorded of five randomly selected plants in a plot and averaged.

\section{Yield (q/ha)}

The total yield obtained from the experimental area was expressed in quintals/hectare.

\section{Results and Discussion}

\section{Number of fruit per cluster}

The data regarding number of fruits per cluster are presented in Table 1 . The data on minimum and maximum number of fruit per cluster of tomato ranges from6.06 to 8.33. The maximum number of fruit per cluster 8.33 was obtained from NAA @ 100 ppm + Boron@75 ppm $\left(\mathrm{T}_{9}\right)$ which was at par with T9 (NAA@ @ 75 ppm + Boron@ @ 75 ppm) (8.33), T T $_{8} \mathrm{GA}_{3} @ 75$ ppm + Boron@75 ppm) 8.20, $\mathrm{T}_{7}\left(\mathrm{GA}_{3} @ 50 \mathrm{ppm}+\right.$ Boron @ 75 ppm) 7.93, T 5 (NAA @ 100 ppm) 7.20, The minimum number of fruit per cluster 6.40 was obtained from control $\left(\mathrm{T}_{1}\right)$.

\section{Number of fruit per plant}

The data accessible on number of fruits per plant of tomato as influenced by different plant growth regulator and boron spray are presented in Table 2. The number of fruits per plant varied from 14.60 to 26.46. The maximum (26.46) fruits per plant were 
recorded at NAA@100 ppm + Boron@75 ppm $\left(\mathrm{T}_{10}\right)$, which was at par with $\mathrm{T}_{9}$ (NAA @ 75 ppm + Boron @ 75 ppm) (25.66), $\mathrm{T}_{8}\left(\mathrm{GA}_{3}\right.$ @ 75 ppm + Boron@75 ppm) (25.13), $\mathrm{T}_{7}$ $\left(\mathrm{GA}_{3} @ 50\right.$ ppm + Boron @ 75 ppm) (24.66), T5 (NAA @ 100 ppm) 24.06 and T4 (NAA @ 75 ppm) 23.53, whereas minimum number of fruits per plant 14.60 was obtained from control $\left(\mathrm{T}_{1}\right)$.

In case of combine effect of plant growth regulators and boron there was significantly increased in number of fruit per cluster and fruit per plant in tomato plants was because of NAA which had protected the flower and premature fruit drop and increased length of fruit size in tomato plants (Mukharji and Roy, 1966). And also NAA is effective in cell elongation and there by increased cell enlargement, cell division and differentiation which in turn results into increase in number of flowers, fruit size, number of fruits and weight it was also reported by (Rodrigues et al., 2001). Similarly $\mathrm{GA}_{3}$ spray on tomato plants reduced fruit drop and contributes better number of fruits per cluster in plants. and also $\mathrm{GA}_{3}$ become more active in presence of extra plant food and hence the number of fruits seems to have increased (Uddain and Hossain, 2009). These findings are in support from the Patel et al., (2012), Ranjeet et al., (2014) and Akand et al., (2015). The Boron application influenced to increase number of flowers, number of inflorescence and number. of fruits. Similar findings were reported by Singh et al., (2011) and Shukla et al., (2017)

\section{Fruit length (cm)}

The observation on fruit length in tomato was recorded on at harvest and presented in Table 3. The minimum fruit length $(4.55 \mathrm{~cm})$ was recorded under the $\mathrm{T}_{1}$ (control) and the maximum fruit length $(7.92 \mathrm{~cm})$ was recorded under the treatment $\left(\mathrm{T}_{10}\right)$ NAA @ 100 ppm + Boron@75 ppm which is followed by $\mathrm{T}_{9}$
(NAA@ @75 ppm + Boron@ @75 ppm) (7.57 $\mathrm{cm}), \mathrm{T}_{8}\left(\mathrm{GA}_{3} @ 75\right.$ ppm + Boron@ 75 ppm) $(7.55 \mathrm{~cm})$ and $\mathrm{T}_{5}$ (NAA @ 100 ppm) (7.41 $\mathrm{cm})$ and $\mathrm{T}_{7}\left(\mathrm{GA}_{3} @ 50 \mathrm{ppm}+\right.$ Boron @ 75 ppm) $(7.30 \mathrm{~cm})$.

\section{Fruit diameter $(\mathrm{cm})$}

The result on fruit diameter has been presented in Table 4. The growth regulators, boron and their combined use were found to be significant in increase of fruit diameter. The assessment of data revealed that fruit diameter $(\mathrm{cm})$ ranged from $4.47(\mathrm{~cm})$ to 7.43 (cm). A maximum fruit diameter of $7.43 \mathrm{~cm}$ was reported by NAA @ 100 ppm + Boron@ 75 ppm $\left(\mathrm{T}_{10}\right)$, which was significantly at par with $\mathrm{T}_{9}$ (NAA @75 ppm + Boron@75 ppm) $6.95 \mathrm{~cm}$ and $\mathrm{T}_{8}\left(\mathrm{GA}_{3} @ 75 \mathrm{ppm}+\right.$ Boron @ $75 \mathrm{ppm}) 6.55 \mathrm{~cm}$., However the minimum fruit diameter recorded was $4.47 \mathrm{~cm}$ under the $\mathrm{T}_{1}$ (control).

\section{Fruit weight}

The results on average fruit weight have been presented in Table 5. The data was recorded minimum and maximum weight of tomato ranges from $41.59 \mathrm{~g}$ to $56.22 \mathrm{~g}$. A maximum fruit weight of $56.22 \mathrm{~g}$ was reported by NAA @ 100 ppm + Boron @ 75 ppm $\left(\mathrm{T}_{10}\right)$, which is statically at par with T 9 (NAA @ 75 ppm + Boron@75 ppm) $55.78 \mathrm{~g}, \mathrm{~T}_{8}\left(\mathrm{GA}_{3} @ 75\right.$ ppm + Boron@75 ppm) $55.15 \mathrm{~g}, \mathrm{~T}_{5}$ (NAA @ 100 ppm) $55.06 \mathrm{~g}, \mathrm{~T}_{7}\left(\mathrm{GA}_{3} @ 50 \mathrm{ppm}+\right.$ Boron@75 ppm) 53.29 g, T4 (NAA @ 75 ppm) $52.52 \mathrm{~g}$ and $\mathrm{T}_{3}\left(\mathrm{GA}_{3} @ 75 \mathrm{ppm}\right) 52.20$ $\mathrm{g}$. Minimum fruit weight of $41.59 \mathrm{~g}$ was reported in $\left(\mathrm{T}_{1}\right)$ control.

Combination of plant growth regulators and boron were significantly influence the fruit length, fruit diameter and fruit weight of tomato. $\mathrm{GA}_{3}$ might be increased accumulation of carbohydrates owing to greater photosynthesis. Gibberellin also be induce 
cell division, cell elongation, cell enlargement and ultimately led to better growth of plants resulted the superior fruit length, fruit diameter and fruit weight of tomato (Choudhary et al., 2004). NAA attributed to the increased supply of photosynthetic materials and efficient mobilization in plants giving rise to increased stimulation of fruit growth ultimately resulting in increased fruit weight, fruit width and fruit length (Bhosle et al., 2002) and (Pundir and Yadav, 2001). On the other hand Boron also needed by the crop plants for cell division, nucleic acid synthesis, uptake of calcium and transport of carbohydrates (Bose and Tripathi 1996), which helped to increase the fruit length, fruit diameter and fruit weight. These results are in close conformity by Meena (2008), Desai et al., (2012), Prasad et al., (2013), Ranjeet et al., (2014) and Verma et al., (2014).

Table.1 Effect of plant growth regulator and boron on number of fruit per cluster of tomato

\begin{tabular}{|c|c|c|}
\hline Treatment & Treatment details & Fruit per cluster \\
\hline $\mathbf{T}_{\mathbf{1}}$ & Control & 6.40 \\
\hline $\mathbf{T}_{\mathbf{2}}$ & $\mathrm{GA}_{3} @ 50 \mathrm{ppm}$ & 6.46 \\
\hline $\mathbf{T}_{\mathbf{3}}$ & $\mathrm{GA}_{3} @ 75 \mathrm{ppm}$ & 6.60 \\
\hline $\mathbf{T}_{\mathbf{4}}$ & NAA @ 75 ppm & 7.13 \\
\hline $\mathbf{T}_{\mathbf{5}}$ & NAA @ $100 \mathrm{ppm}$ & 7.20 \\
\hline $\mathbf{T}_{\mathbf{6}}$ & Boron @ 75 ppm & 6.40 \\
\hline $\mathbf{T}_{\mathbf{7}}$ & $\mathrm{GA}_{3} @ 50 \mathrm{ppm}+$ Boron @ 75 ppm & 7.93 \\
\hline $\mathbf{T}_{\mathbf{8}}$ & $\mathrm{GA}_{3} @ 75 \mathrm{ppm}+$ Boron @ 75 ppm & 8.20 \\
\hline $\mathbf{T}_{\mathbf{9}}$ & NAA @ 75 ppm + Boron @ 75 ppm & 8.31 \\
\hline $\mathbf{T}_{\mathbf{1 0}}$ & NAA @ $100 \mathrm{ppm}+$ Boron @ $75 \mathrm{ppm}$ & 8.33 \\
\hline $\mathbf{S E m} \pm$ & & 0.42 \\
\hline $\mathbf{C D}(\mathbf{P}=\mathbf{0 . 0 5})$ & & 1.26 \\
\hline
\end{tabular}

Table.2 Effect of plant growth regulator and Boron on number of fruit per plant of tomato

\begin{tabular}{|c|c|c|}
\hline Treatment & Treatment details & No. of fruit per plant \\
\hline $\mathbf{T}_{\mathbf{1}}$ & Control & 14.60 \\
\hline $\mathbf{T}_{\mathbf{2}}$ & $\mathrm{GA}_{3} @ 50 \mathrm{ppm}$ & 18.86 \\
\hline $\mathbf{T}_{\mathbf{3}}$ & $\mathrm{GA}_{3} @ 75 \mathrm{ppm}$ & 19.80 \\
\hline $\mathbf{T}_{\mathbf{4}}$ & NAA @ 75 ppm & 23.53 \\
\hline $\mathbf{T}_{\mathbf{5}}$ & NAA @ $100 \mathrm{ppm}$ & 24.06 \\
\hline $\mathbf{T}_{\mathbf{6}}$ & Boron @ 75 ppm & 16.46 \\
\hline $\mathbf{T}_{\mathbf{7}}$ & $\mathrm{GA}_{3} @ 50 \mathrm{ppm}+$ Boron @ 75 ppm & 24.66 \\
\hline $\mathbf{T}_{\mathbf{8}}$ & $\mathrm{GA}_{3} @ 75 \mathrm{ppm}+$ Boron @ 75 ppm & 25.13 \\
\hline $\mathbf{T}_{\mathbf{9}}$ & NAA @ 75 ppm + Boron @ 75 ppm & 25.66 \\
\hline $\mathbf{T}_{\mathbf{1 0}}$ & NAA @ 100 ppm + Boron @ 75 ppm & 26.46 \\
\hline $\mathbf{S E m} \pm$ & & 1.78 \\
\hline $\mathbf{C D}(\mathbf{P}=\mathbf{0 . 0 5})$ & & 5.28 \\
\hline
\end{tabular}


Table.3 Effect of plant growth regulator and boron on fruit length of tomato

\begin{tabular}{|c|c|c|}
\hline Treatment & Treatment details & Fruit length $(\mathrm{cm})$ \\
\hline $\mathrm{T}_{1}$ & Control & 4.55 \\
\hline $\mathbf{T}_{2}$ & $\mathrm{GA}_{3} @ 50 \mathrm{ppm}$ & 6.45 \\
\hline $\mathbf{T}_{3}$ & $\mathrm{GA}_{3} @ 75 \mathrm{ppm}$ & 6.56 \\
\hline $\mathbf{T}_{4}$ & NAA@75 ppm & 7.20 \\
\hline $\mathbf{T}_{5}$ & NAA@100 ppm & 7.41 \\
\hline $\mathbf{T}_{6}$ & Boron@75 ppm & 5.83 \\
\hline $\mathbf{T}_{7}$ & $\mathrm{GA}_{3} @ 50$ ppm + Boron@75 ppm & 7.30 \\
\hline $\mathbf{T}_{8}$ & GA $3 @ 75$ ppm + Boron@75 ppm & 7.55 \\
\hline $\mathbf{T}_{9}$ & NAA@75 ppm + Boron@75 ppm & 7.57 \\
\hline $\mathbf{T}_{10}$ & NAA@100 ppm + Boron @ 75 ppm & 7.92 \\
\hline SEm \pm & & 0.22 \\
\hline $\mathrm{CD}(\mathrm{P}=\mathbf{0 . 0 5})$ & & 0.67 \\
\hline
\end{tabular}

Table.4 Effect of plant growth regulator and boron on fruit diameter $(\mathrm{cm})$ of tomato

\begin{tabular}{|c|c|c|}
\hline Treatment & Treatment details & Fruit diameter $(\mathrm{cm})$ \\
\hline$T_{1}$ & Control & 4.47 \\
\hline $\mathbf{T}_{2}$ & $\mathrm{GA}_{3} @ 50 \mathrm{ppm}$ & 5.33 \\
\hline $\mathbf{T}_{3}$ & $\mathrm{GA}_{3} @ 75 \mathrm{ppm}$ & 5.71 \\
\hline $\mathbf{T}_{4}$ & NAA@75 ppm & 5.79 \\
\hline $\mathbf{T}_{5}$ & NAA@100 ppm & 6.38 \\
\hline $\mathbf{T}_{6}$ & Boron@75 ppm & 5.10 \\
\hline $\mathbf{T}_{7}$ & $\mathrm{GA}_{3} @ 50$ ppm+Boron@75 ppm & 5.87 \\
\hline $\mathbf{T}_{8}$ & GA 3 @75 ppm+Boron@75 ppm & 6.55 \\
\hline $\mathbf{T}_{9}$ & NAA@75 ppm + Boron@75 ppm & 6.95 \\
\hline $\mathbf{T}_{10}$ & NAA@100 ppm + Boron@ 75 ppm & 7.43 \\
\hline SEm \pm & & 0.33 \\
\hline $\mathrm{CD}(\mathrm{P}=\mathbf{0 . 0 5})$ & & 0.98 \\
\hline
\end{tabular}

Table.5 Effect of plant growth regulator and boron on fruit weight of tomato

\begin{tabular}{|c|c|c|}
\hline Treatment & Treatment details & Fruit weight $(\mathbf{g})$ \\
\hline $\mathbf{T}_{\mathbf{1}}$ & Control & 41.59 \\
\hline $\mathbf{T}_{\mathbf{2}}$ & $\mathrm{GA}_{3} @ 50 \mathrm{ppm}$ & 46.86 \\
\hline $\mathbf{T}_{\mathbf{3}}$ & $\mathrm{GA}_{3} @ 75 \mathrm{ppm}$ & 52.20 \\
\hline $\mathbf{T}_{\mathbf{4}}$ & NAA @ $75 \mathrm{ppm}$ & 52.52 \\
\hline $\mathbf{T}_{\mathbf{5}}$ & NAA @ $100 \mathrm{ppm}$ & 55.06 \\
\hline $\mathbf{T}_{\mathbf{6}}$ & Boron @75 ppm & 42.36 \\
\hline $\mathbf{T}_{\mathbf{7}}$ & $\mathrm{GA}_{3} @ 50 \mathrm{ppm}+$ Boron @ 75 ppm & 53.29 \\
\hline $\mathbf{T}_{\mathbf{8}}$ & $\mathrm{GA}_{3} @ 75 \mathrm{ppm}+$ Boron @ $75 \mathrm{ppm}$ & 55.15 \\
\hline $\mathbf{T}_{\mathbf{9}}$ & NAA @ 75 ppm + Boron @75 ppm & 55.78 \\
\hline $\mathbf{T}_{\mathbf{1 0}}$ & NAA @ $100 \mathrm{ppm}+$ Boron @ $75 \mathrm{ppm}$ & 56.22 \\
\hline $\mathbf{S E m} \pm$ & & 2.82 \\
\hline $\mathbf{C D}(\mathbf{P}=\mathbf{0 . 0 5})$ & & 8.38 \\
\hline
\end{tabular}


Table.6 Effect of plant growth regulator and boron on average yield per plant of tomato

\begin{tabular}{|c|c|c|}
\hline Treatment & Treatment details & Average yield per plant (kg) \\
\hline $\mathrm{T}_{1}$ & Control & 0.62 \\
\hline $\mathbf{T}_{2}$ & $\mathrm{GA}_{3} @ 50 \mathrm{ppm}$ & 1.03 \\
\hline $\mathbf{T}_{3}$ & $\mathrm{GA}_{3} @ 75 \mathrm{ppm}$ & 1.24 \\
\hline $\mathbf{T}_{4}$ & NAA@ @ 75 ppm & 1.30 \\
\hline $\mathbf{T}_{5}$ & NAA@100 ppm & 1.37 \\
\hline $\mathbf{T}_{6}$ & Boron@75 ppm & 0.88 \\
\hline $\mathbf{T}_{7}$ & $\mathrm{GA}_{3} @ 50$ ppm + Boron@75 ppm & 1.33 \\
\hline $\mathbf{T}_{8}$ & $\mathrm{GA}_{3} @ 75$ ppm + Boron @ 75 ppm & 1.42 \\
\hline $\mathbf{T}_{9}$ & NAA@75 ppm + Boron@75 ppm & 1.49 \\
\hline $\mathbf{T}_{10}$ & NAA@100 ppm + Boron@75 ppm & 1.69 \\
\hline SEm \pm & & 0.07 \\
\hline $\mathrm{CD}(\mathbf{P}=\mathbf{0 . 0 5})$ & & 0.21 \\
\hline
\end{tabular}

Table.7 Effect of plant growth regulator and boron on average yield ( $\mathrm{q} / \mathrm{ha}$ ) of tomato

\begin{tabular}{|c|c|c|}
\hline Treatment & Treatment details & yield $(\mathbf{q} / \mathbf{h a})$ \\
\hline $\mathbf{T}_{\mathbf{1}}$ & Control & 203.09 \\
\hline $\mathbf{T}_{\mathbf{2}}$ & $\mathrm{GA}_{3} @ 50 \mathrm{ppm}$ & 286.55 \\
\hline $\mathbf{T}_{\mathbf{3}}$ & $\mathrm{GA}_{3} @ 75 \mathrm{ppm}$ & 338.43 \\
\hline $\mathbf{T}_{\mathbf{4}}$ & NAA @ 75 ppm & 404.52 \\
\hline $\mathbf{T}_{\mathbf{5}}$ & NAA @ $100 \mathrm{ppm}$ & 440.52 \\
\hline $\mathbf{T}_{\mathbf{6}}$ & Boron @ 75 ppm & 226.15 \\
\hline $\mathbf{T}_{\mathbf{7}}$ & $\mathrm{GA}_{3} @ 50 \mathrm{ppm}+$ Boron @ 75 ppm & 431.53 \\
\hline $\mathbf{T}_{\mathbf{8}}$ & $\mathrm{GA}_{3} @ 75 \mathrm{ppm}+$ Boron @ 75 ppm & 457.96 \\
\hline $\mathbf{T}_{\mathbf{9}}$ & NAA @ 75 ppm + Boron @ 75 ppm & 470.33 \\
\hline $\mathbf{T}_{\mathbf{1 0}}$ & NAA @ 100 ppm + Boron @ 75 ppm & 490.81 \\
\hline $\mathbf{S E m} \pm$ & & 22.79 \\
\hline $\mathbf{C D}(\mathbf{P}=\mathbf{0 . 0 5})$ & & 67.74 \\
\hline
\end{tabular}

\section{Average yield per plant}

The result on yield per plant has been presented in the Table 6. Maximum yield 1.69 kg per plant was obtained with NAA @ 100 ppm + Boron@ 95 ppm $\left(\mathrm{T}_{10}\right)$ and lowest yield $0.62 \mathrm{~kg}$ per plant was obtained with control $\left(\mathrm{T}_{1}\right)$.

\section{Yield (q/ha)}

The result on yield per hectare has been presented in the Table 7 . The maximum yield
490.81 q/ha was obtained by NAA @ 100 ppm + Boron@75 ppm $\left(\mathrm{T}_{10}\right)$, which was at par with $\mathrm{T}_{9}$ (NAA@ @ 75 ppm + Boron@ 75 ppm) 470.33 q/ha, $\mathrm{T}_{8}\left(\mathrm{GA}_{3} @ 75 \mathrm{ppm}+\right.$ Boron@75 ppm) 457.96 q/ha, T5 (NAA @ $100 \mathrm{ppm}) 440.52 \mathrm{q} / \mathrm{ha}$ and $\mathrm{T}_{7}\left(\mathrm{GA}_{3} @ 50 \mathrm{ppm}\right.$ +Boron@75 ppm)431.53 q/ha. And the lowest yield $203.09 \mathrm{q} / \mathrm{ha}$ was obtained with control $\left(\mathrm{T}_{1}\right)$.

The yield was significantly affected by plant growth regulators and Boron. The increased 
in yield was attributed might be due to enhanced the plant growth and faster rate of the plant development by the action of NAA in the cell elongation, cell division and cell differentiation which in turn result into increase in number of flowers, fruit set, size and weight of fruit. Similar increase in yield had also been reported by Raj et al., (2012), Nibhavanti et al., (2004) and Singh and Sant (2005.)

\section{References}

Akand, Md., Hassnuzzam., Mazed, H. E. M., Khairul, Pulok, Md. Ashraful Islam., Choudhry, Md. Shah Newaz and Moonmoon, Jannatul Ferdous. 2015. Growth and yield of tomato (Lycopersicon esculentum) as influenced by different level of gibberelic acid application, International Journal of Applied Research, 1(3): $71-74$.

Anonymous. 2015. Department of agriculture cooperation and farmer welfare. www.agricoop.nic.in

Anonymous. 2016. IGKV Agriculture diary.

Batlang U. 2008. Benzyl adenine plus gibberellins (GA4+7) increase fruit size and yield in greenhouse-grown hot pepper (Capsicum annuum L.). J. Biolog. Sci., 8(3): 659-662.

Bhosle, A. B., Khorbhade, S. B., Sanap, P. B. and Gorad, M. J. 2002. Effect of plant hormones on growth and yield of summer tomato (Lycopersicon esculentum Mill). Orissa J. Hort. 30(2): 63-65.

Bose, T. K. and Som, M. G. 1990. Vegetable crops in India. Naya Prakash, Calcutta, India. pp. 687-691.

Chaudhary, B.R., Sharma, M.D., Shakya, S.M. and Gautam, D.M. 2006 Effect of plant growth regulators on growth, yield and quality of chilli (Capsicum annum L.) J Inst. Agric. Anim. Sci.
27: 65-68.

Desai, S.S., Chovatia R. S. and Singh, V. 2012. Effect of different plant growth regulators and micronutrients on fruit quality and plant micronutrient content of tomato. Int. J. Agril. Sci. 100(1): 130-133.

Meena, R.S., 2008. Effect of $\mathrm{GA}_{3}$ and NAA on growth yield and quality of tomato cv. Pusa ruby growth under semi-arid condition. Current Agri. 31(1-2): 83 86.

Mukherji, S.K. and Roy, B.K. 1966. Reducing fruit drop in West Bengal. World Crops, 18(3): 34.

Nibhavanti, B.K., Bhalekar M. N., Gupta N. S. and Deshpande A. N. 2004. Effect of growth regulators on growth and yield of tomato. J. Maharashtra Agri. Uni, 31(1): 64-65.

Patel, J. S., Sitapara, H. H. and Patel, K. A. 2012. Influence of plant growth regulators on growth, yield and quality of tomato and brinjal. Int. J. For. Crop Improv., 3(2): 116-118.

Prasad, R.N., Singh, S. K., Yadava, R. B. and Chaurasia, S. N. S. 2013. Effect of GA3 and NAA on growth and Yield of tomato. Vegetable science. 40(2): 195-197.

Pundir, J.P.S., and Yadav, P. K. 2001. Effect of GA3, NAA and 2, 4-D on growth, yield and quality of tomato var. Punjab Chhuhara. Current Agri., 25: $1-2$.

Raj, P.T.S., Nagaraja, M. S., Dhumgond, P., Reddy, Sharanbhoopal and Shivakumar, K. M. 2012. Effect of foliar application of secondary and micro nutrients on yield and quality of tomato. Asian J. Soil Sci., 7(2): 194199.

Ranjeet, R.B., Ram, J. P. and M. L. Meena. 2014. Growth, flowering, fruiting, yield and quality of tomato (Lycopersicon esculentum Mill.) as 
influenced plant bio regulators. Int. J. Plant Sci., 9(1): 67-71.

Singh, R., and Sant A. K. 2005. Effect of plant growth regulators and micronutrient mixture on the growth and yield of tomato. Bioved, 16 (1-2): 101-105.

Singh, Y., and Singh, S. S. 2011. Effect of different concentration of plant growth regulators on the yield and quality attributes of tomato (Lycopersicon esculentum Mill). Veg. Sci., 38(2): 228-230.

Shukla, P.C., and Dixit, Amit. 2017. Effect of foliar application of micronutrients on growth and yield of tomato
(Lycopersicon esculentum Mill) cv. ArkaRakshak. Trends in biosciences, 10 (32): 6736-6738.

Udden, J., Hossain, K.M.A., Mostafa, M.G. and Rahman, M.J., 2009. Effect of different plant growth regulators on growth and yield of tomato. International Journal of Sustainable Agriculture, 1(3): 58-63.

Verma, P., Pratap S., Meena, M. L. and Meena, K. S., 2014. Influence of plant growth regulators on growth, Flowering and quality of Tomato (Lycopersicon esculentum Mill), cv. H-86. Indian Journal of Hill Farming, 27(2): 19-22.

\section{How to cite this article:}

Shweta Gupta and Deepti Patel. 2020. Study on Effect of Plant Growth Regulators and Boron on Fruit Yield Attributes of Tomato (Solanum lycopersicum Mill.). Int.J.Curr.Microbiol.App.Sci. 9(05): 3457-3464. doi: https://doi.org/10.20546/ijcmas.2020.905.410 